\title{
Preferensi Konsumsi Keluarga Perspektif Ekonomi Islam (Studi Kasus di Kelurahan Wates, Ngaliyan Kota Semarang)
}

\author{
Mansur \\ Institut Agama Islam Negeri Salatiga \\ mansur_ismailnaimah@yahoo.com
}

\begin{abstract}
Abtract
This study aims to determine the consumption preference of Moslem family in Wates Ngaliyan Semarang in the perspective of Islamic economics and the factors that influence the consumption preference of Moslem family in Wates Ngaliyan Semarang. This research is field research using descriptive qualitative approach. The results of this research are that family consumption preference still over consumption or israf, but there are some Moslem families suitable to consumption preference in Islam, and There is other factor influencing consumption preference which is social environment.
\end{abstract}

Keywords: Preference, Moslem family, Islamic Economic

\begin{abstract}
Abstrak
Penelitian ini bertujuan untuk mengetabui preferensi konsumsi keluarga muslim di Wates Ngaliyan Semarang dalam perspektif ekonomi Islam dan faktor-faktor yang mempengarubi preferensi konsumsi keluarga muslim di Wates Ngaliyan Semarang. Penelitian ini merupakan penelitian lapangan dengan menggunakan pendekatan kualitatif deskriptif. Hasil penelitian ini dapat disimpulkan bahwa preferensi konsumsi keluarga masib bersikap israf (berlebib-lebihan. Namun ada dari beberapa keluarga muslim sesuai dengan preferensi konsumsi dalam Islam. Ada faktor lain yang mempengarubi preferensi konsumsi yakni lingkungan sosial.
\end{abstract}

Kata Kunci : Preferensi Konsumsi Keluarga, Ekonomi Islam

Permalink/DOI:http://dx.doi.org/10.18326/infsl3.v11i2.409-430 


\section{Pendahuluan}

Hidup manusia yang perlu dipenuhi setiap hari adalah persoalan ekonomi. Oleh karena itu manusia berkewajiban memelihara dan mengembangkan agar potensi sumber daya ekonomi di dunia ini bisa dimanfaatkan oleh generasi seterusnya. Persoalan ekonomi mengandung tiga aspek yakni produksi, konsumsi dan distribusi. Konsumsi adalah hal yang berkaitan dengan pemenuhan kebutuhan barang dan jasa yang benar-benar dibutuhkan. Salah satu permasalahan adalah kebutuhan konsumsi barang dan jasa. Pemenuhan kebutuhan, setiap individu selalu dihadapkan pada berbagai pilihan (preferensi) yang ada di pasar. Hal ini membuat sejumah keputusan tentang bagaimana mengalokasikan sumber daya untuk memenuhi berbagai kebutuhan dan juga harus memilih penggunaan uang untuk membeli barang atau jasa yang dibutuhkan dalam kehidupan sehari-hari. Memilah-milah barang dan jasa yang dibutuhkan bertujuan agar pendapatan yang diterima tidak lebih besar pasak dari pada tiang. Dalam surat al-A'raf ayat 31 Allah Swt berfirman :

Wahai anak cucu Adam, pakailah pakaianmu yang bagus pada setiap memasuki masjid, makan dan minumlah, tetapi jangan berlebihan. Sesunggubnya Allah tidak menyukai orang-orang yang berlebihan-lebihan.

Kebutuhan individu terdiri dari kebutuhan primer, sekunder dan tersier. Kebutuhan primer adalah kebutuhan yang harus atau wajib terpenuhi yakni papan sandang pangan, Artinya apabila kebutuhan tersebut tidak terpenuhi, maka manusia akan mengalami kesulitan dalam hidupnya. Adapun kebutuhan sekunder adalah kebutuhan yang sifatnya melengkapi kebutuhan primer dan kebutuhan itu baru terpenuhi setelah kebutuhan primer terpenuhi. Kebutuhan tersier timbul setelah kebutuhan primer dan sekunder terpenuhi. Jika seseorang merasa lebih, maka kebutuhan tersier termasuk kelompok mewah, karena pemenuhan kebutuhannya tertuju pada barang-barang mewah yang hanya dilakukan oleh orang yang pendapatannya besar karena kebutuhan primer dan sekunder sudah terpenuhi dan tidak hanya sekedar cukup. 
Dalam menentukan pilihan kebutuhandalam konsumsiharus menyeimbangkan antara kebutuhan preferensi dan ketersediaan sumber daya. Fungsi permintaan lahir bersumber dari keputusan manusia untuk memilih barang dan jasa yang dibutuhkan. Fungsi permintaan termasuk salah satu bagian dari kegiatan masyarakat untuk mengkonsumsi suatu barang (P3EI, 2008:173). Sedangkan menurut ekonomi konvensional, konsumen hanya berorientasi pada tujuan untuk memperoleh kepuasan/utility dalam kegiatan konsumsinya. Bahwa ekonomi Islam morallah sebagai basic dalam setiap aktivitas (Nasution, 2006: 120). Sebab kepuasan sebagai tujuan konvensional dalam konsumsi karena menganggap bahwa sumber daya ekonomi terbatas guna memenuhi kebutuhan manusia akan barang dan jasa setiap hari, sehingga kelompok rugi jika seorang konsumen mengkonsumsi barang dan jasa tidak merasakan kepuasan terhadap barang atau jasa yang dikonsumsi. Ilmu ekonomi konvensional tidak membedakan antara kebutuhan (needs) dan keinginan (wants), sehingga ekonomi konvensional lebih dekat bersifat materialistic hedonistic, artinya tidak hanya sekedar cukup tetapi lebih dan lebih. Konsumsi dalam Ilmu konvensional merupakan fungsi dari keinginan, nafsu, harga barang, pendapatan, dan lain-lain namun mengesampingkan aspek spiritual. Konvensional menganggap aspek spiritual berdiri sendiri tidak bisa berintegrasi dengan wilayah ilmu ekonomi, mengkonsumsi barang yang haram misalnya alkohol dan rokok, menguras minyak bumi, menebangi hutan, serta proses industri yang menimbulkan polusi dan air merupakan contoh nyata yang bersifat merusak. Tidak ada yang dapat menghalangi perilaku bomo economicus kecuali kemampuan anggaran dana yang dimiliki oleh seseorang. Kegiatan ekonomi tidak ada keterkaitan sifat peduli terhadap masa depan diri sendiri di dunia, bahkan untuk masa depan kelak di akhirat. Dalam ilmu ekonomi konvensional tidak ada larangan dan tidak ada anjuran di dalam kegiatan ekonomi yang terpenting bagaimana cara memuaskan utilitas individu. Nasution (2010: 68-69). Dengan konsep ekonomi konvensional mengajak manusia untuk konsumsi lebih mengedepankan kepuasaan diri sendiri dan hanya bersifat dunia dapat terpenuhi apa yang diinginkan. 
Menurut ilmu ekonomi, konsumsi merupakan kegiatan menggunakan atau memakai barang dan jasa secara langsung untuk memenuhi kebutuhan manusia. Konsumsi berhubungan erat dengan tingkat pendapatan penggunaan barang dan jasa untuk memenuhi kebutuhan manusia. Konsumsi tidak hanya menyangkut menghabiskan lewat makan dan minum saja, tetapi juga kegiatan ekonomi lainnya seperti membeli dan memakai barang dan jasa. Pengertian konsumsi menurut ekonomi Islam tidak berbeda dengan definisi tersebut. Namun kesamaan pengertian tidak berarti kesamaan dalam setiap yang meliputinya. Sebab, barang dan jasa yang dipergunakan dalam memenuhi kebutuhan seorang muslim dan keinginannya harus halal. Sebagaimana kebutuhan dan keinginan tersebut juga harus benar sesuai syariah. (P3EI, 2008:145), selain itu dalam ekonomi Islam juga memperhatikan kepeduliaan orang lain dan keluarga yang serba kekurangan serta mempertimbangkan maslahab daripada kepuasan individu. Adapun dalam ekonomi Islam mengkonsumsi barang dan jasa lebih mengedepankan kemaslahatan, jangan berlebihan / israf atau mubadzir, sehingga lebih berorientasi pada keseimbangan dan memilah-milah barang dan jasa yang dikonsumsi serta memperhatikan pemanfaatan anggaran dana yang wajar.

Konsumsi dalam ekonomi Islam sangat terintegrasi dengan keimanan seseorang, sehingga iman seseorang menjadi tolok ukur dalam melakukan preferensi konsumsi, karena keimanan memberikan cara pandang dunia yang cenderung mempengaruhi kepribadian manusia, keimanan seseorang akan mempengaruhi untuk memilih barang dan jasa yang akan dikonsumsi. Keimanan menjadi filter dalam membelanjakan harta dan sekaligus juga memotivasi pemanfaatan pendapatan untuk hal-hal yang efektif halal dan maslahah. Seseorang berhak membelanjakan uang untuk memenuhi kebutuhan karena Islam menganjurkan seseorang memegang uang memiliki dua motif yakni uang untuk bertransaksi dan yang kedua digunakan untuk berjaga-jaga.

Konsumsi dalam ekonomi Islam ada yang dianjurkan dan ada yang dilarang, adapun yang dianjurkan adalah barang atau jasa yang dihalalkan oleh syariat Islam, jika kehahalalan barang atau jasa sudah didapat maka akan mendapatkan keberkahan dan 
keberkahan akan mendapatkan pahala, adapun motifuntuk berjagajaga artinya untuk konsumsi di hari tua baik lewat menabung atau dengan cara diinvestasikan. Dengan motivasi berjaga-jaga agar manusia tidak mudah jatuh miskin dan tidak perlu berhutang. Gaya hidup keluarga akan mempengaruhi preferensi konsumsi barang ataupun jasa, oleh karena itu keluarga yang boros, di mana setiap mendapatkan pendapatan habis dibelanjakan barang yang tidak ada manfaatnya yang penting barang atau jasa yang dikonsumsi menghasilkan kepuasan bagi konsumennya. Oleh karena itu konsumsi untuk diri sendiri juga kepedulian dengan aspek sosil atau masyarakat agar terwujud keseimbangan dalam memenuhi kebutuhan-kebutuhan. (An-Nabhani, 2002: 272). Hal tersebut dalam Islam menolak, karena ada kebutuhan yang lebih penting harus terpenuhi terlebih dahulu yakni kebutuhan primer, baru diikuti kebutuhan sekunder yang terakhir tersier.

Preferensi konsumsi dalam keluarga dipengaruhi baik faktor internal maupun eksternal yakni dari pendapatan, kebutuhan, serta lingkungan. Preferensi konsumsi keluarga dapat dijadikan sebagai perbedaan antara keluarga mapan atau keluarga kekurangan. Oleh karena itu keluarga yang mapan jangan menimbulkan kecemburuan dengan tetangga yang masih kekurangan dan sebaliknya keluarga yang serba kekurangan jangan mengikuti gaya konsumsinya keluarga yang sudah mapan.

Berdasar hal tersebut di atas penelitian ini fokus menganalisis preferensi konsumsi keluarga perspektif ekonomi Islam (studi kasus Kelurahan Wates Kecamatan Ngaliyan Kota Semarang tahun 2017)

\section{Tinjauan Pustaka}

Penelitian Putiani (2015) dalam Pola Perilaku Konsumsi Islami Mahasiswa Muslim Fakultas Ekonomi dan Bisnis Universitas Airlangga Ditinjau dari Tingkat Religiusitas, menjelaskan bahwa mahasiswa muslim dalam membelanjakan harta dari orang tuanya digunakan secara Islami sehingga bisa membedakan antara belanja mahasiswa muslim dengan mahasiswa non muslim. 
Ghafur (2016) juga meneliti tentang Konsumsi dalam Islam menjelaskan bahwa konsumsi itu bagaikan raja sehingga dalam jurnal ini dijelaskan bahwa itu tujuan ekonomi konvensional, padahal ekonomi Islam tidak hanya sekedar konsumsi tetapi merupakan pemenuhan kebutuhan perintah pada Allah semata. Oleh karena dalam konteks adanya keizinan untuk mengkonsumsi rezeki yang diberikan Allah sekaligus terpikul tanggung jawab untuk memberikan perhatian terhadap keperluan hidup orang yang tidak punya.

Muntholip (2017) dalam jurnalnya Perilaku Konsumsi Dalam Perspektif Islam menerangkan bahwa dengan banyaknya perdagangan yang masuk ke dalam negeri Indonesia dan perkembangan ekonomi di bidang industri masyarakat dalam mengkonsumsi semakin tak terbatas dalam mengkonsumsi barang ataupun jasa, semakin banyak jenis dan kualitas barang dan jasa yang diinginkan konsumen.

\section{Preferensi Konsumsi}

Dalam ilmu ekonomi konvensional bahwa preferensi konsumsi yang mengasumsikan bahwa barang atau jasa yang dikonsumsi memberikan tingkat yang sama dalam memberikan kepuasan, sehingga barang atau jasa tersebut banyak dipilih oleh seseorang. Karena dasar konsumsi dalam konvensional adalah rasionalitas artinya secara rasio wajar seseorang mengkonsumsi barang karena cukup anggaran dan barang yang dikonsumsi memberikan kepuasan (Karim. 2007:51). Ilmu ekonomi konvensional seseorang memilih barang yang memuaskan karena memiliki nilai yang sama bagi konsumen tidak ada yang lebih berharga atau lebih penting dan tidak ada yang dilarang atau dianjurkan sepanjang memberikan tingkat kepuasan yang sama bagi konsumen. Contoh buah jeruk bermanfaat untuk menambah vitamin $C$ agar tubuh segar dan sehat sedangkan narkoba merusak kesehatan dan perlu dijauhi namun bagi konsumen konvensional dianggap bernilai sama dan dikonsumsi selagi barang tersebut memberikan kepuasan bagi konsumen. 
Dalam preferensi konsumsi lebih berorientasi pada kepuasan yang setinggi-tingginya, sehingga kelompok kualitas dan kuantitas barang atau jasa akan dikonsumsi jika dapat memberikan kepuasan yang tinggi bagi konsumen. Sejalan dengan tujuan pembangunan umat hendaknya mampu memenuhi kebutuhan secara utuh. Oleh karena Islam menganggap mengemis sebagai profesi yang tidak selaras dengan sebutan khalifatul fil ardhi (Chapra, 2000: 8). Dalam memilih barang atau jasa yang dikonsumsi hanya bisa dibatasi oleh sejumlah anggaran keuangan yang dimiliki oleh konsumen dengan cara bekerja yang halal dan terhormat. Sehingga kombinasi pilihan konsumen terhadap benda ekonomi berdasarkan anggaran keuangan yang dimilikinya tidak ada nilai lain yang prinsip yang menjadi kendala dalam memilih barang atau jasa yang dibutuhkan setiap hari. Tendensi kepuasan cenderung menghabiskan anggaran demi mengejar kepuasan tertinggi yang sudah menjadi kebiasaan sehari-hari. Kepuasaan yang semaksimal mungkin harus dicapai walaupun anggaran keuangan dengan cara berhutang. Menurut Qardhawi ada 3 norma dasar yang hendaknya menjadi landasan dalam perilaku konsumen muslim (Anto, 2003: 139-140). Inilah prinsip-prinsip yang perlu dipegang oleh seorang muslim dalam melakukan pemilihan barang atau jasa yang dikonsumsi yakni, a) Membelanjakan harta dalam kebaikan dan menjauhi sifat kikir. Harta diberikan Allah kepada manusia seharusnya bisa dimanfaatkan dengan cara disaving untuk tujuan berjaga-jaga agar hidupnya tidak dalam kesulitan. Jika sudah dimanfaatkan, maka seseorang wajib berorientasi demi kemaslahatan yang berorientasi pada ketentuan nilai-nilai Islam. Dalam memilih barang atau jasa untuk dikonsumsi yang berorientasi pada kemaslahatan diwajibkan dalam Islam namun sebaliknya Islam melarang boros ataupun kikir sekalipun. b) Tidak Melakukan kemubadziran, Mengkonsumsi barang atau jasa benar-benar yang bermanfaat dan sesuai dengan kebutuhan yang dibutuhkan oleh setiap orang muslim. Jangan melakukan konsumsi yang berlebih-lebihan bahkan pemborosan. Sifat mubazir juga dihindari dalam pembelanjaan publik juga. Dalam pembelanjaan publik hendaknya menetapkan kriteria prioritas, (Azmi, 2005: 204) Menetapkan kreteria prioritas juga dianjurkan dalam pemunuhan konsumsi agar tidak terjebak 
pada sifat boros apalagi biar dianggap orang lain kaya, maka gaya hidupnya trendi. Oleh karena sikap-sikap memilih barang atau jasa dikonsumsi hendaknya memperhatikan sikap yakni menjauhi utang, menjaga asset yang mapan dan pokok, tidak hidup mewah dan boros. c) Kesederhanaan, Dalam konsidi ekonomi krisis dalam memilih konsumsi bersikap hemat, membelanjakan hartanya pada kuantitas dan kualitas barang atau jasa secukupnya lebih baik. Dengan kesederhanaan dapat memberikan dampak positif bagi lingkungan sekitarnya. Preferensi konsumsi mengedepankan sederhana, maka akan banyak harta yang disaving demi untuk hari tua yang tidak pasti. Kesederhanaan di sini bukan berarti kikir namun harus adanya keseimbangan memilih konsumsi barang ekonomi harus imbang antara konsumsi duniawi dan konsumsi akherat, yang berupa zakat infak sodaqoh (ZIS). Dengan demikian keseimbangan ini akan menghasilkan kemaslahatan tidak hanya sekedar kepuasan hidup di dunia semata.

\section{Want and Need}

Dalam ekonomi islam tujuan memilih barang dan jasa yang akan dikonsumsi adalah falah artinya preferensi konsumsi bertendensi pada kemaslahatan dan kemudharatan barang dan jasa yang dikonsumsi sehingga barang yang bermaslahah lebih dipilih dari pada yang tidak ada manfaatnya dan yang mudharat perlu di hindari atau di jauh tidak perlu dijadikan pilihan konsumsi dalam keluarga. Oleh karena itu want/keinginan yang digunakan dasar ilmu konvensional. Bahwa keinginan merupakan penggerak dalam pemilihan konsumsi untuk mencapai kepuasan terhadap barang dan jasa yang dikonsumsi (Rozalinda, 2015: 104). Keinginan tidak melihat kemanfaatan dan kerugian yang penting memberikan kepuasan. Islam menolak keinginan seorang karena want itu hanya menuruti hawa nafsu setan. Oleh karena itu keinginan yang berlebihan perlu dikendalikan dan diarahkan sehingga membawa kemaslahatan.

Adapun need merupakan kebutuhan yang digunakan sebagai penggerak untuk memilih konsumsi barang dan jasa yang lebih bermanfaat. Need di sini dikelompokkan yakni kebutuhan primer yakni sandang papan pangan baru kebutuhan 
sekunder kemudian tersier. Islam lebih dekat pada need dari pada want karena need merupakan kebutuhan yang benar-benar dibutuhkan dalam kehidupan seseorang untuk menjalankan kelangsungan hidup di dunia.

\section{Maslahab dan Utility}

Tujuan preferensi konsumsi dalam Islam adalah mencari kemaslahatan atau kemanfaatan bukan utilitas atau kepuasan, karena kepuasan itu cenderung menuruti hawa nafsu setan, beda dengan kemaslahatan lebih bersifat obyektif daripada kepuasan bersifat subyektifitas artinya kepuasan seseorang berbeda dengan orang lain tetapi kemaslahatan berlaku bagi semua orang karena bersifat obyektif yang berorientasi pada kemanfaatan bukan kepuasan. Kemaslahatan bersumber dari need seseorang yang mengkonsumsi barang atau jasa, sehingga kebutuhan preferensi konsumsi berdasarkan pada maslahah tidaknya dalam mengkonsumsi berbagai variasi benda ekonomi. Sehingga neet itu berdasarkan norma dan etika agar mendapatkan kemaslahatan baik dunia dan akherat (Rozalinda, 2015:108). Konsep utility apabila dianalisis dari konsep mashlahah, bahwa kepuasan bukan didasarkan atas banyaknya barang maupun bagusnya barang yang dipilih untuk dikonsumsi tetapi didasarkan atas baik buruknya sesuatu terhadap diri dan lingkungannya. Jika memilih barang ekonomi yang akan dikonsumsi akan mendatangkan mafsadah (kerusakan) pada diri atau lingkungan maka tindakan itu harus ditinggalkan. Bila dalam memilih barang ekonomi untuk di konsumsi dihadapkan buah simalakama dalam mengonsumsi sesuatau kemungkinan mengandung mudarat atau mashlahat maka seorang muslim memilih barang ekonomi lebih baik menghindari kemudaratan harus diutamakan, karena akibat dari kemudaratan yang ditimbulkan dari preferensi konsumsi mempunyai ekses yang lebih besar dari pada mengambil sedikit manfaat. Bukan berarti konsumsi yang tidak kualitas tetapi justru berkualitas atau modern dan pertengahan sebagai karate dalam Islam (Ahmad Ibrahim Abu Sinn, 2008: 7). Oleh karena itu Islam justru menganjurkan agar keuangan digunakan untuk belanja yang lebih maslahah bukan hanya semata kepuasan diri sendiri. Dapat dikatakan bahwa 
kepuasan dijadikan sumber dalam preferensi konsumsi tidak akan mendapatkan kemanfaatan karena kepuasan merupakan suatu akibat atas terpenuhinya suatu keinginan, sedangkan mashlahah merupakan akibat atas terpenuhinya suatu kebutuhan juga yang akan memberikan kepuasan terutama jika kebutuhan tersebut disadari dan diinginkan. Jika pemilihan konsumsi berorientasi pada maslahah, maka kemaslahatan individu mesti konsisten dengan maslahah sosial, karena kemaslahatan yang dirasakan dirinya pasti maslahah bagi orang lain dan sebaliknya. Preferensi konsumsi bersumber pada kemaslahatan maka setiap orang muslim mampu menyusun prioritas dan pentahapan pemenuhan kebutuhan barang dan jasa yang dibutuhkan setiap hari. Jika preferensi konsumsi dilakukan dengan tujuan mencari kemaslahatan, maka hasilnya akan falah baik dunia maupun akherat.

\section{Hukum Utilitas dan Mashlahah}

Untuk melakukan pemilihan barang atau jasa yang dikonsumsi hendak keluarga lebih dikombinasikan dan bervariasi untuk menghindari kebosanan. Mengonsumsi suatu barang atau jasa secara terus menerus secara berurutan maka nilai tambahan kepuasan yang diperolehnya semakin menurun. Dengan demikian melakukan preferensi sangat penting karena setiap hari makan daging terus maka kebosanan akan terjadi, akan menjadi kejenuhan yang menyebabkan orang merasa kurang senang, kurang nikmat dan sejenisnya. Dilihat dari hukum kelangkaan suatu barang yang jumlahnya langka, dan oleh karena itu konsumsinya juga sedikit maka nilai barang tersebut tinggi (Sudarsono, 2002: 152). Demikian juga sebaliknya, meskipun hukum mengenai utilitas marginal ini berlaku secara umum dalam teori ekonomi konvensional, namun ada beberapa pengecualian. Pengecualian yang tidak termasuk dalam kategori adalah pemilihan konsumen yang menunjukkan adanya kecanduan (addicted). Kepuasan ini hanya bersifat dunia sementara saja yang langsung dapat dirasakan. Oleh karena itu hukum mengenai penurunan utilitas marginal tidak selamanya berlaku pada mashlahah. Adapun hukum mashlahah pada konsumsi tidak seluruhnya secara langsung dapat dirasakan, terutama mashlahah akhirat atau berkah. Adapun mashlahah 
dunia manfaatnya sudah bisa dirasakan setelah dikonsumsi. Dalam hal berkah, dengan meningkatnya frekuensi kegiatan, maka tidak akan ada penurunan berkah karena pahala yang diberikan atas ibadah tidak pernah menurun hanya Allah saja yang tahu hal tersebut. Sedangkan mashlahah dunia akan meningkat dengan meningkatnya frekuensi kegiatan, namun pada level tertentu akan mengalami penurunan. Hal ini dikarenakan tingkat kebutuhan manusia di dunia adalah terbatas sehingga ketika konsumsi dilakukan secara berlebih-lebihan, maka akan terjadi penurunan mashlahah duniawi. Dengan demikian kegiatan mashlahah akan memberikan "warna" dari kegiatan yang dilakukan oleh konsumen muslim.

\section{Tujuan Preferensi Konsumsi}

Tujuan preferensi dalam ilmu ekonomi konvensional hanya ingin mencapai utility atau kepuasan. Selain tercapainya kepuasan juga anggaran dana yang penting mencukupi untuk memilih barang yang dikonsumsi yang penting barang yang dikonsumsi menghasilkan kepuasan bagi konsumen. Sehingga tujuan preferensi konsumsi konvensional lebih bersifat self interest artinya hanya mementingkan diri sendiri tanpa peduli dengan orang lain. Selain self interest juga bersifat materialistic bedonistic artinya tujuan preferensi konsumsi dalam mengkonsumsi barang yang diinginkan tidak hanya sekedar cukup tapi ingin yang lebih dan lebih.

Preferensi konsumsi ekonomi Islam memiliki tujuan yang beda dengan preferensi konsumsi konvensional. Ekonomi Islam memilki tujuan yakni falah artinya dalam memilih barang atau jasa yang dikonsumsi harus berdasarkan manfaat dunia dan akherat. Memperhatikan dunia dan akherat sesungguhnya bermuara pada akidah Islam yang bersumber al-Quran dan al-Hadits (Huda dkk, 2008: 1). Dengan demikian dalam memilih mampu mempertimbangkan apakah barang yang dipilih untuk dikonsumsi maslahah atau madharat.. oleh karena itu preferensi konsumsi agar tercapai tujuan dalam ekonomi Islam hendaknya harus mengutamakan akherat dari pada dunia artinya seseorang dalam 
memilih barang yang akan dikonsumsi hendaknya berorientasi ibadah yang tidak hanya memilih barang ekonomi yang bersifat dunia semata tetapi juga harus memilih barang ekonomi untuk akherat. Memilih barang ekonomi untuk preferensi konsumsi akherat manakala seorang konsumen memperhatikan adab saat mengkonsumsi barang ekonomi kemudian harus memperhatikan perolehan barang ekonomi dan harta yang diperoleh selain dibelanjakan barang yang halal dan manfaat serta harta tersebut juga harus di zakati (Anto, 2003: 124). Agar barang yang dipilih untuk dikonsumsi berdampak dunia sekaligus berdampak akherat juga.

Preferensi konsumsi ekonomi Islam hendaknya konsisten dalam perioritas artinya dalam memilih barang ekonomi untuk memenuhi kebutuhan sehari-hari ada tahapannya. Adapun tahapannya daruriyyah / kebutuhan primer/ kebutuhan dasar, tahapan hajjiyah artinya kebutuhan sekunder/ kebutuhan pelengkap, tahapan terakhir tahsiniyyah artinya kebutuhan tersier/ kebutuhan kemewahan. Preferensi konsumsi juga memperhatikan etika dan norma, jika etika dan norma dijadikan pedoman dalam pemilihan barang ekonomi yang akan dikonsumsi, maka falah akan tercapai sebagai tujuan preferensi konsumsi ekonomi Islam.

\section{Faktor-Faktor Yang Mempengaruhi Preferensi Konsumsi}

Faktor internal merupakan faktor yang berasal dalam diri sendiri, sehingga pribadi atau seseorang yang melakukan pemilihan konsumsi tergantung pada pribadi seseorang yang mengkonsumsi tersebut. Faktor internal pribadi yang meliputi:

1. Keimanan artinya keimanan seseorang akan mempengaruhi preferensi konsumsi seseorang, jika seorang muslim akan lebih mengedepankan akhlaknya karena mengkonsumsi itu merupakan bagian ibadah (Ahmad, 1979: 135), sehingga makan itu tidak hanya sekedar kenyang tapi juga mendapat ibadah tidak hanya sekedar mengisi perut agar kenyang namun juga mendapatkan keberkahan dari makan yang sesuai dengan nilai-nilai Islam. Jika hanya menuruti hawa nafsu maka akan menyebabkan tingginya inflasi (BI, 2017:4). Tingginya inflasi 
salah satunya disebabkan masyarakat cenderung konsumsi tinggi tidak memperhatikan kebutuhan konsumsi.

2. Latarbelakang pendidikan artinya asal usul sekolah itu juga dapat mempengaruhi preferensi konsumsi, sehingga pendidikan yang tamatan sekolah dasar berbeda dengan seseorang yang berpendidikan SMP dan seterusnya. Sehingga latar belakang tamatan pendidikan itu akan mempengaruhi preferensi konsumsi. Jika semakin tinggi pendidikan, maka preferensi konsumsinya semakin lebih baik dan sebaliknya pendidkan akan mempengaruhi pendapatan yang diperolehnya (Sudarsono, 2002: 159). Pendapatan, artinya pendapatan ini berasal dari individu. Oleh karena itu semakin banyak pendapatannya maka dalam preferensi juga akan sangat bervariasi. Pendapatan akan mempengaruhi seseorang memilih barang atau jasa yang akan dikonsumsi karena semakin banyak pendapatan maka semakin banyak pula pilihan barang ekonomi yang dipilihnya. Islam mengajarkan bahwa membelanjakan harta tidak boleh melampaui batas.

3. Keluarga, artinya faktor keluarga merupakan faktor yang berasal dari diri pribadi seseorang melakukan pilihan konsumsi, sehingga setiap pribadi wajib menjalankan kewajibannya untuk mencari rezki (Sari, 2005: 8). Oleh karena itu keluarga mulai sedini mungkin perlu melakukan pendidikan dalam konsumsi, jika dari didikan keluarga sudah mengedepankan pemilihan barang ekonomi yang menghasilkan kemanfaatan dari pada madharat, maka seseorang dalam menentukan pilihan konsumsi kemungkinan besar akan mengutakan konsumsi akherat, konsisten serta memperhatikan etika dan norma.

Faktor eksternal adalah faktor yang mempengarungi preferensi konsumsi yang berasal dari luar diri seseorang. Adapun faktor eksternal yakni lingkungan, yang mana lingkungan masyarakat dan lingkungan sejawat dan media sosial. Faktor ligkungan masyarakat sanga besar pengaruhnya terhadap preferensi konsumsi, karena seseorang akan melihat gaya hidup tetangganya akan mempengaruhi pemilihan barang ekonomi yang akan dikonsumsi. Contohnya seseorang melihat yang 
berpenampilan dengan pakaian ala keartisan, maka pada saat ada anggaran dana mereka akan meniru apa yang diinginkan.

Faktor yang berasal dari lingkungan sejawat artinya teman yang setiap harinya bertemu dalam suatu pekerjaan. Setiap hari berinteraksi dengan teman kerja maupun teman bermain/teman bergaul akan cepat mempengaruhi dalam preferensi barang ekonomi yang dikonsumsi oleh orang tersebut. Oleh karena itu seseorang hendaknya memilih teman yang tepat agar dalam preferensi barang ekonomi tidak salah pilih. Jika salah pilih barang ekonomi maka akan menghasilkan kemadharatan dalam hidupnya. Tetapi jika pilih teman yang tepat baik akhlaknya maka akan dapat pengaruh yang baik, sehingga dalam preferensi konsumsi akan menghasilkan kemanfaatan dunia dan akherat.

Faktor media sosial yang berasal dari faktor eksternal yang datang dari luar diri seseorang. Media sosial dalam kondisi modern serba internat dengan cepat dan mudah informasi yang diinginkan akan ditemukan. Oleh karena itu media sosial sangat besar pengaruhnya terhadap gaya hidup seseorang untuk melakukan preferensi konsumsi melalui transaksi online langsung didapat apa yang diinginkan tanpa membutuhkan waktu lama dan anggaran dana memadai. Media sosial bisa mempengaruhi gaya hidup seseorang boros atau hemat. Seseorang yang boros cenderung dipengaruhi oleh gaya hidup trend bermerk atau wah yang berkeinginan agar diakui oleh orang dan dianggap dirinya paling kaya padahal sebenarnya masuk kategori orang yang paspasan atau kelompok miskin.

\section{Metode Penelitian}

Penelitian ini adalah penelitian lapangan (field research), dengan menggunakan metode deskriptif kualitatif yang menghasilkan data deskriptif berupa kata-kata, gambar dan bukan angka-angka, dilakukan secara langsung berhubungan dengan obyek yang diteliti yaitu keluarga Muslim Wates Ngaliyan Semarang. Penelitian ini bertujuan untuk mendeskripsikan dan menganalisis preferensi atau mengurutkan konsumsi keluarga muslim di Wates Ngaliyan Semarang. Kemudian data wawancara dilakukan deskripsi oleh 
peneliti dan memahami fenomena dari subyek penelitian melalui komitmen mengurutkan dan persepsi terhadap konsumsi barang atau jasa untuk memenuhi kebutuhan sehari-hari.

\section{Analisis}

\section{Preferensi Konsumsi Keluarga Perspektif Ekonomi Islam}

Preferensi konsumsi keluarga dalam perspektif ekonomi Islam, artinya seorang konsumen muslim dalam memilih barang ekonomi yang akan dikonsumsi akan mempertimbangkan manfaat dan keberkahan yang akan dicapai pada saat kegiatan memilih konsumsinya. Preferensi konsumsi keluarga merupakan kebutuhan primer yang saling berinteraksi intensif serta dukungan emosional yang kuat dengan anggota keluarga. Masing-masing keluarga dalam memilih barang ekonomi yang dikonsumsi berbeda-beda baik berdasarkan selera maupun keinginan.

Kebutuhan keluarga sangat berbeda-beda, sehingga setiap anggota keluarga juga mengalami perbedaan dalam memilih konsumsi bahkan pemilihan barang ekonomi yang akan dikonsumsi belum mesti terpenuhi karena terbatasnya anggaran dana yang dimiliki suatu keluarga, misalnya anak ingin membeli mainan motor remot, tidak selalu dituruti oleh orang tuanya. Karena keluarga lebih membutuhkan barang ekonomi yang lebih penting, sehingga preferensi keluarga lebih mengutamakan need yang perlu diprioritaskan dalam pemilihan konsumsi. Keluarga tersebut masih pada tahapan keluarga yang wajib memenuhi kebutuhan primer saja.

\section{Mengutamakan Akherat daripada Dunia.}

Memilih konsumsi untuk dirinya maupun semua anggota keluarga hendaknya lebih yang bermanfaat. Kemanfaatan ini tidak hanya untuk dunia tetapi juga untuk akherat. Tetapi sebaliknya jangan memilih barang ekonomi yang tidak ada manfaatnya tetapi memberikan kepuasan bagi konsumen alias boros. Isam melarang tindakan konsumsi boros yang tidak mempertimbangkan manfaat atau tidak. Membelanjakan harta tidak boleh melampaui batas dengan tujuan supaya kebutuhan keluarga terpenuhi 
dan tidak berutang pada orang lain hanya gara-gara membeli barang ekonomi yang tidak ada manfaatnya, namun keluarga tidak boleh mengharamkamkan hartanya untuk keluarga sendiri karena adanya dorongan sifat pelit dan bakhil tidak dibenarkan senagaja mempersuli keluarga dengan dalih beribadah atau hidup masih panjang perlu menghemat uangnya, mempersulit keluarga termasuk perbuatan tercela. Dalam ekonomi Islam manusia dianjurkan mensyukuri nikmat apapun dan berapapun harta yang didapat agar tetap dimanfaatkan untuk mencapai falah hidupnya. Praktek pemilihan konsumsi keluarga di Wates Ngaliyan Semarang ada yang sudah baik dan ada keluarga yang membelanjakan harta tidak melampaui batas bahkan masih banyak memilih konsumsi melampaui batas mengejar trend atau gaya hidup glamour bahkan memilih konsumsi hanya mengejar hawa nafsu semata tanpa memikirkan bagaimana kebutuhan akan datang. Orang tua merasa kasihan pada anaknya saat keinginanya tidak dituruti.padahal terkadang keinginan anaknya terulang seperti itu terus. Beberapa keluarga menyadari bahwa preferensi konsumsi yang tidak mengutamakan akherat berdampak tidak baik dalam keluarganya. Yang mana akan membengkaknya pengeluaran akan tetapi masih dilakukan, karena kurang mengontrol pengeluaran keluarga, sehingga mengakibatkan mengandalkan hutang ke tetangga maupun ke komunitas oragnisasi dalam masyarakat. Berdasarkan penelitian ini, banyak keluarga petani, buruh industri, buruh banguna, ibu ruah tangga, pedagang, dan mata pencaharian sebagai angkutan dan pendapatan tetap misalnya PNS, mereka mempunyai alasan tersendiri, mengapa mereka mementingkan kebutuhan anak dan mengandalkan hutang. Preferensi konsumsi keluarga yang mereka lakukan ada yang belum sesuai dalam membelanjakan harta untuk mengutamakan akherat dari pada dunia. Ketika ada kesempatan untuk menuruti keinginan preferensi konsumsi maka keluarga juga menuruti hal tersebut. Ada sebagian keluarga tidak memikirkan dampak yang akan terjadi apabila mengandalkan hutang. Padahal hutang tidak dianjurkan dalam Islam. Ekonomi Islam dalam preferensi konsumsi keluarga sudah terpenuhi dengan baik, maka keluarga harus mempunyai rasa syukur. Pemilihan pemenuhan kebutuhan akan memberikan 
manfaat fisik, spiritual. Ekonomi Islam tidak melarang keluarga untuk memenuhi kebutuhan atau keinginan selama pemilihan konsumsi tersebut martabat keluarga bisa meningkat. Keluarga diperintahkan untuk memilih barang ekonomi yang dikonsumsi secara wajar tanpa berlebihan.

\section{Konsisten Dalam Prioritas Pemenuban Kebutuban}

Seorang muslim dalam preferensi konsumsi sangat urgen untuk dilakukan setiap keluarga. Sangat urgennya, maka setiap keluarga berbeda-beda dalam melakukan pemilihan barang ekonomi yang dipilih sebagai bahan yang dikonsumsi. Walaupun adanya perbedaan dalam pemilihan konsumsi keluarga karena terdapat prioritas diantara satu dengan lainnya tetapi harus menunjukkan tingkat kemanfaatan dan kemenkelurahankan dalam pemenuhannya. Oleh karena itu ada tiga tingkatan prioritas pemenuhan kebutuhan yang harus dilakukan oleh setiap keluarga muslim secara konsisten, yakni daruriyyah atau kebutuhan primer yang harus dipenuhi pertama dan utama. Kebutuhan primer merupakan suatu kebutuhan yang wajib dipenuhi secara cepat jika diabaikan akan membahayakan bagi manusia misalnya papan jika seseorang belum punya rumah sebagai tempat tinggal maka akan membahayakan jiwa keluarganya walaupun rumah kontrak bisa membuat nyaman semua anggota keluarga, sandang jika seseorang tidak memakai baju maka membahayakan untuk dirinya maupun orang lain, sedangkan kebutuhan pangan jika tidak makan akan menimbulkan kelaparan atau kematian anggota keluarganya minimal makan dua kali sehari. Ada beberapa keluarga yang menerapkan kebutuhan primer dulu, tidak akan memikirkan kebutuhan hajjiyah atau sekunder.

Kebutuhan hajjiyah atau kebutuhan sekunder yakni kebutuhan kedua yang merupakan kebutuhan pelengkap jika kebutuhan kedua ini dipenuhi akan meningkatkan nilai tambah bagi aktivitas manusia misalnya papan tidak hanya sekedar untuk bisa berteduh dari panas dan hujan tapi bisa dilengkapi dengan berbagai asesoris rumah tangga yang sehat dan memadai, Sandang dipenuhi tidak hanya sekedar kain yang bisa menutupi tubuh 
tapi mampu memenuhi dengan pakaian yang mahal sesuai yang diharapkan, sedangkan pangan tidak hanya sekedar dipenuhi makan apa adanya namun dilengkapi jumlah gizi dan vitamin yang terkandung dalam makanan yang dikonsumsi.

Kebutuhan tabsiniyyah yang merupakan kebutuhan yang ketiga jika akan dipenuhi, sehingga tahapan preferensi konsumsi yang terakhir jika dipenuhi akan memberikan kepuasan atau kenikmatan bagi seorang yang sudah pada tahapan ketiga, biasanya seseorang yang sudah lebih dalam pendapatan yang diterimanya. Misalnya papan atau rumah, tidak hanya sekedar berbentuk rumah tetapi besar dan mewah megah, sandang tidak hanya pakaian bagus namun juga bermerk demikian juga pangan yang bermerk juga.

Seorang muslim dalam preferensi konsumsi hendaknya melakukan secara urut dan konsisten terhadap prioritas agar tidak hanya sekedar mengkonsumsi tetapi harus diurutkan mana barang ekonomi yang harus dipenuhi terlebih dahulu agar kebutuhan hidupnya terpenuhi. Jika sudah mampu mengurutkan juga harus diikuti prioritas secara konsisten dalam memenuhi kebutuhan misalnya seseorang yang mata pencaharian buruh bangunan saat ramai maka pendapatan setiap minggu didapat dan pada saat itu anaknya minta uang untuk beli buku pelajaran dan saat itu juga anak bungsunya yang berumur 3 tahun minta dibelikan mainan seharga seratus ribu, maka wajib mengalokasikan anggaran untuk pemenuhan kebutuhan membeli buku sekolah anak sulungnya terlebih dahulu. Di sinilah seorang muslim dalam melakukan preferensi konsumsi keluarga mampu mengurutkan dan memprioritaskan mana yang lebih dulu dipenuhi baru kemudian urutan yang paling rendah.

\section{Memperhatikan Etika Dan Norma}

Seseorang muslim dalam memenuhi preferensi konsumsi keluarga juga harus memperhatikan etika dan norma. Oleh karena itu proses preferensi konsumsi hendaknya dipenuhi unsur etika dan norma agar tidak mubadzir atau sia-sia tidak mendaptkan keberkahan dalam menentukan pilihan konsumsi. Memperhatikan etika berarti memperhatikan baik dan buruknya pemilihan 
pemenuhan kebutuhan terutama mengkonsumsi barang atau jasa, selain memperhatikan etika juga harus memperhatikan norma yakni harus sesuai dengan aturan. Karena pada dasarnya konsumsi dapat dijadikan perantara untuk menambahkan kekuatan dalam mentaati Allah, jika seseorang muslim memiliki indikasi ini berarti seseorang tersebut tidak akan merugikan dirinya maupun keluarga karena dalam memilih konsumsi sudah sesuai urutan kebutuhan dan memperhatikan etika dan norma Islam. Preferensi konsumsi lebih mengutamakan keakheratan dan mampu mengurutkan kebutuhan juga harus memperhatikan unsur kesederhanaan, kebersihan, halalan tayyiban dan lain-lain.

\section{Kesederhanaan (Menjaubi Hutang, Hidup Mewah Dan Boros)}

Dalam ekonomi Islam dianjurkan hidup untuk memeuhi kebutuhan hidup lebih bersifat sederhana. Kesederhanaan akan menjauhi sifat jahat yagng sejalan dengan isu sekarang yang berkembang banyaknya pejabat yang melakukan korupsi yang dikarena hidupnya jauh dari kesederhanaan karena mereka lebih bersifat hidup mewah gemerlapan. Hidup yang ingin disanjung orang lain akan menyiksa diri sendiri bahkan sering menghalalkan segala cara melalui korupsi atau pencucian uang. Oleh karena itu hidup mewah atau dalam kelompok social climberyakni komunitas orang miskin yang berlagak orang kaya agar diakui kelompok kaya dari orang lain dapat merugikan diri sendiri.

Social climber akan mengakibatkan perbuatan korupsi, sering hutang, hal ini termasuk kelompok orang yang hidup boros. Pemborosan yang bersifat materialis hidup dunia dilarang dalam Islam. Karena pemborosan sama dengan mengikuti keinginan hawa nafsu setan belaka tanpa memperhatikan akibat dari perbuatan borosnya. Akibat hidup boros menimbulkan aspek eksternal kecemburuan sosial dan tingkat inflasi semakin tinggi. Sedangkan aspek internal hidupnya tidak tenang dan tidak pernah bersyukur kepada Allah karena dirinya merasa berkurang. Kondisi aspek internal diselimuti hafa nafsu setan karena berambisi dirinyalah yang harus nomor satu. 
Aspek makro, ekonomi inflasi diakibatkan orang banyak memilih konsumsi dalam tingkat boros, jika sebaliknya dalam pemilihan konsumsi hidunya penuh kesederhanaan dalam waktu pendek akan mempengaruhi pertumbuhan ekonomi namun lambat laun adaptasi akan berjalan lancar tanpa hambatan. Kesederhanaan merupakan perilaku hidup masarakat yang berprinsip ekonomi Islam.

\section{Faktor Yang Mempengarubi Preferensi Konsumsi Keluarga}

Faktor internal adalah factor yang berasal dari diri sendiri yang meliputi personal dan keluarga. Personal mengandung unsur akidah, ibadah akhlak, keluarga, pekerjaaan , pendapatan dan latar belakang pendidikan. Sedangkan unsur keluarga terdiri dari unsur pekerjaan, pendapatan dan latar belakang pendidikan. Faktor pribadi yakni akidah, ibadah akhlak akan mempengaruhi preferensi konsumsi keluarga. Preferensi konsumsi keluarga sangat berbeda-beda tergantung dari tingkat keimanan atau akidah, semakin tinggi tingkat keimananya maka semakin tinggi konsistensi dalam mengurutkan dan prioritas yang akan dipenuhi kebutuhan keluarganya. Faktor keluarga yang terdiri pekerjaan, pendapatan dan latar belakang pendidikan juga mempengaruhi preferensi konsumsi keluarga. Semakin tinggi pendapatan dan pendidikan maka semakin berbeda-beda untuk melakukan preferensi konsumsi membelanjakan harta bagi orang pendapatannya meningkat akan memberikan peluang bagi konsumen untuk memperbesar konsumsinya guna menaikkan tingkat maslahah maksimum. Oleh karena itu bagi muslim hendaknya memenuhi kebutuhannya harus diperbesar konsumsi ibadahnya agar lebih maslahah maksimumnya.

Faktor Ekternal merupakan faktor yang bersumber di luar diri sendiri, yakni faktor lingkungan. Lingkungan merupakan lingkungan masyarakat atau lingkungan seikitar di mana mereka berinteraksi dengan orang lain. Lingkungan bisa disebut masyarakat atau bisa lingkungan sesama teman. Faktor ini sangat besar pengaruhnya terhadap seseorang melakukan pemenuhan kebutuhan sehari-hari. Oleh karena itu hendaknya memilih 
lingkungan dan teman yang baik agar mendapatkan pengaruh yang semakin hari semakin baik. Berkaitan preferensi konsumsi mendapatkan pengaruh lingkungan yang materialistik maka seseorang akan meniru gaya yang setiap hari dilihat dan saksikan.

\section{Kesimpulan}

Preferensi konsumsi keluarga perspektif ekonomi Islam lebih mengurutkan tingkatan kebutuhan dan konsisten dengan prioritas yang hendak dipenuhi lebih dahulu. Dengan demikian seorang muslim lebih mengutamakan yang lebih utama dan mana yang lebih menkelurahank untuk dijadikan prioritas konsumsi yang harus dilaksanakan agar kebutuhan penting dan menkelurahank itu terpenuhi dengan baik sesuai dengan ajaran Islam. Meningkatnya pendapatan biasanya akan diimbangi dengan meningkatnya belanja seseorang. Oleh karena dalam membelanjakan anggarannya perlu memperhatikan kemaslahatan atau keberkahannya, harus mampu menyeimbangkan antara kebutuhan material dan spiritual. Dengan keseimbangan tersebut akan melahirkan konsumsi duniawi dan konsumsi akherat, maka semakin meningkat pendapatan akan semakin tinggi konsumsi ibadahnya. Sehingga dapat memprioritaskan atau bisa secara urut konsumsi yang dibutuhkan setiap hari, maka dapat melakukan managemen financial dengan jalan menyisihkan uang antara 10$15 \%$ penghasilan setiap bulan untuk berjaga-jaga mempersiapkan hari tua sekaligus bisa mengendalikan tingkat inflasi. 